Bulletin of the Natural History Museum, 2018, 11: 211-214.

Received 05 Jun 2018; Accepted 26 Oct 2018.

doi: $10.5937 /$ bnhmb $1811211 \mathrm{~K}$

UDC: $582.542 .12(497.11)$

Short communication

\title{
ON THE ALLEGED PRESENCE OF CAREX ATHERODES (CYPERACEAE) IN SERBIA
}

\author{
JACOB KOOPMAN $^{1 *}$, HELENA WIĘCŁAW ${ }^{2}$ \\ ${ }^{1}$ ul. Kochanowskiego 27, 73-200 Choszczno, Poland; jackoopman@e-cho.pl \\ ${ }^{2}$ Department of Plant Taxonomy and Phytogeography, Institute for Research on \\ Biodiversity, Faculty of Biology University of Szczecin, Wąska 13, 71-415 \\ Szczecin, PL; wieclawh@univ.szczecin.pl
}

Carex atherodes Spreng. (Cyperaceae) is a species from the Subarctic and Temperate Northern Hemisphere, which occurs in N America, Europe and northern Asia (Govaerts et al., continuously updated). From E and N Europe and the Caucasus it is known from eleven countries, in most of which it is a rare species: Armenia, Belarus, Estonia, Finland, Georgia, Germany, Latvia, Poland, Russia, Sweden, and Ukraine (Koopman 2015). It is absent in W and S Europe. However, Jiménez-Mejías et al. (2012) mentioned it for Bosnia-Herzegovina and Serbia. Peculiarly they mentioned that "Both studied vouchers showed short hairs only over the ligule; while, in contrast, utricles, stems, leaves and remains of basal sheaths were complete glabrous." Both authors of the current communication know $C$. atherodes well from Poland, where it is in the northwestern Province of Zachodniopomorskie rather abundant at some places (Rutkowski 2014). The cited sentence above drew our attention and curiosity, as in Poland we have never seen such glabrous material. Therefore we asked for a loan of 
the Serbian material in BUNS: Carex atherodes, SERBIA: Vojvodina, Novi Sad, Petrovaradin, Tekije Rit.; 23 June 1971, leg. Branislawa Butorac; originally inserted as C. pseudocyperus L.; rev. P. Jiménez-Mejías, June 2010, as C. atherodes.

Based on the comparison of the Serbian material with material of Carex atherodes from Poland we have come to the conclusion that the Serbian material is not Carex atherodes. The Serbian plant is bold, no hairy leaf

Table 1. Comparison of Serbian specimen with C. atherodes.

\begin{tabular}{|c|c|c|c|}
\hline Character & Serbian plant & $\begin{array}{l}\text { Carex atherodes } \\
\text { from Poland }\end{array}$ & $\begin{array}{l}\text { Carex atherodes } \\
\text { (according to } \\
\text { Reznicek \& } \\
\text { Catling 2002) }\end{array}$ \\
\hline $\begin{array}{l}\text { Hairiness of leaf } \\
\text { sheaths }\end{array}$ & bold & hairy & hairy \\
\hline Ligule & $\begin{array}{l}10 \mathrm{~mm} \text { long, } \\
\text { rounded at the top }\end{array}$ & & (6-)11-45 mm \\
\hline $\begin{array}{l}\text { Inflorescence } \\
\text { length }\end{array}$ & $17 \mathrm{~cm}$ & up to $45 \mathrm{~cm}$ & $12-60 \mathrm{~cm}$ \\
\hline $\begin{array}{l}\text { Number of male } \\
\text { spikes }\end{array}$ & 2 & $3-4$ & $2-6$ \\
\hline $\begin{array}{l}\text { Number of female } \\
\text { spikes }\end{array}$ & 3 & 3 & $2-5$ \\
\hline Female glumes & $\begin{array}{l}\text { very narrow, dark } \\
\text { violet, with green } \\
\text { midrib, not } \\
\text { aristate }\end{array}$ & $\begin{array}{l}\text { pale with a very } \\
\text { long arista }\end{array}$ & $\begin{array}{l}\text { lanceolate to } \\
\text { narrowly ovate, } \\
\text { apex acute, } \\
\text { conspicuously } \\
\text { scabrous-awned }\end{array}$ \\
\hline Utricles & $\begin{array}{l}5 \mathrm{~mm} \text {, ribbed, } \\
\text { teeth of beak } \\
\text { upright, not } \\
\text { spreading; empty; } \\
\text { bold }\end{array}$ & $\begin{array}{l}10 \mathrm{~mm} \text {; teeth of } \\
\text { beak } 3 \mathrm{~mm} \text {, } \\
\text { spreading, } \\
\text { sparsely hairy }\end{array}$ & $7-12 \mathrm{~mm}$ \\
\hline
\end{tabular}

sheaths, the utricles are half as long as those of $C$. atherodes and the female glumes differ (see Table 1). On the other hand it is very probably not Carex pseudocyperus either, with two male spikes at the top and with the weird, very small female glumes. As the utricles are empty, we suppose it may concern a hybrid, with Carex pseudocyperus involved. According to Koopman (2015) there are two hybrids known of C. pseudocyperus, namely with $C$. rostrata Stokes [C. ×justi-schmidtii Junge] and with $C$. 
vesicaria $\mathrm{L}$. [C. $\times$ wolteri Gross]. Because of the dark glumes maybe even C. acutiformis Ehrh. is involved, although the hybrid of C. acutiformis and C. pseudocyperus is so far unknown to science, so not very probable. All three mentioned species, C. rostrata, C. vesicaria and C. acutiformis occur in Serbia, as does C. pseudocyperus. It is hard to say which hybrid it really concerns, as the material in BUNS is just one single flowering stem, some poorly collected material. However, Jermy et al. (2007) give a description and drawing of $C$. × justi-schmidtii and at least our material does not look like that hybrid. Besides, the presence of Carex rostrata in Vojvodina is doubtful. There are a few old records (Zorkóczy 1896, as C. ampullacea; Prodán 1915). It has not been found in Vojvodina recently. In Serbia, $C$. rostrata has only been recorded for mountainous areas (pers. com. M. Niketić). It should not be excluded either that the material discussed here concerns some weird material of one of the mentioned species above, apart from C. pseudocyperus. Anyway, it is for sure not C. atherodes.

\section{CONCLUSION}

The Serbian material is not Carex atherodes. Originally it was determined as C. pseudocyperus, so we assume that it was growing in a clump, like C. pseudocyperus does, whereas $C$. atherodes grows rhizomatous. As long as there is no convincing material of $C$. atherodes from Serbia, this species should not be added to An Annotated Checklist of Vascular Flora of Serbia (Niketić \& Tomović 2018), being mentioned erroneously by Jiménez-Mejías et al. (2012).

\section{Acknowledgements}

We are grateful to Milica Rat, the curator of BUNS, for sending us as a loan the material of the so-called $C$. atherodes.

\section{REFERENCES}

Govaerts, R., Jiménez-Mejías, P., Koopman, J., Simpson, D. A., Goetghebeur, P., Wilson, K. L., Egorova, T. V., Bruhl, J. J. (2016): World checklist of Cyperaceae. Facilitated by the Royal Botanic Gardens, Kew. [http://apps. kew.org/wcsp/] (accessed: 27 May 2018).

Jermy, A. C., Simpson, D. A., Foley, M. J. Y., Porter, M. S. 2007. Sedges of the British Isles. BSBI Handbook no.1, ed. 3. - Botanical Society of the British Isles, London. 
Jiménez-Mejías, P., Martín-Bravo, S., Rat, M., Anačkov, G., Luceño, M. (2012): New records of Southeast European Carex L. (Cyperaceae). - Biologia Serbica 34(1-2): 100-102.

Koopman, J. (2015): Carex Europaea, ed. 2, 1 (e-book). - Margraf Publishers, Weikersheim.

Niketić, M., Tomović, G. (2018): An annotated Checklist of Vascular Flora of Serbia 1. Lycopodiopsida, Polypodiopsida, Gnetopsida, Pinopsida and Liliopsida. - Serbian Academy of Sciences and Arts, Belgrade. (in press)

Prodán, Gy. (1915): Bács-Bodrog vármegye flórája. - Magyar Botanikai Lapok 14(5-12): 120-269.

Reznicek, A. A., Catling. P. M. (2002): Carex L. sect. Carex. In: Ball, P. W., Reznicek, A. A., Murray, D. F. (eds): Flora of North America north of Mexico 23. - Oxford University Press, New York, Oxford.

Rutkowski, L. (2014): Carex atherodes Sprengel. In: Kaźmierczakowa, R., Zarzycki, K., Mirek, Z. (eds): Polish red data book of plants. Pteridophytes and flowering plants, ed. 3. - Polish Academy of Sciences, Institute of Nature Conservation, Cracow.

Zorkóczy, L. (1896): Újvidék és környékének florája: 128 pp. - Popovits M. Testvérek Könyvnyomdája, Üjvidék [Novi Sad].

\title{
O НАВЕДЕНОМ ПРИСУСТВУ CAREX ATHЕRODES (CYPERACEAE) У СРБИЈИ
}

\author{
JACOB KOOPMAN, HELENA WIĘCŁAW
}

\section{Р Е 3 И М Е}

Ревизијом хербарског материјала (BUNS) установљено је да је претходни навод о присуству врсте Carex atherodes Spreng. у Србији погрешан. Прегледани примерак првобитно је био идентификован као C. pseudocyperus, због чега претпостављамо да је биљка формирала компактне бусенове, као што је случај код C. pseudocyperus, насупрот C. atherodes који образује дуге пузеће ризоме. У Jiménez-Mejías et al. (2012) погрешно је поменуто да је биљка уврштена у Критичку листу васкуларне флоре Србије (Niketić \& Tomović 2018). Све док не постоји уверљиви материјал о присуству ове врсте у Србији, њу не треба уврстити у поменуту публикацију. 